\title{
OCENIANIE OKRESOWE A INNE DZIALANIA ZE SFERY REALIZACJI FUNKCJI PERSONALNEJ W ORGANIZACJI
}

\section{Wstęp}

Systemy oceniania okresowego są niezbędne dla prawidłowej oceny efektywności oraz skutecznego zarządzania pracownikami ${ }^{1}$. Ich rola jest szczególnie ważna, ponieważ ocena jest punktem wyjścia dla innych działań z obszaru realizacji funkcji personalnej w organizacji. To formalne narzędzie jest używane przy podejmowaniu decyzji przez menedżerów w zakresie wynagrodzeń, awansów czy degradacji ${ }^{2}$. Ocenianie okresowe jest oczywiście wykorzystywane również w celach rozwojowych $-\mathrm{np}$. w określaniu potrzeb szkoleniowych pracowników i ocenie efektów szkolenia ${ }^{3}$. Znaczenie systemów oceniania okresowego związane jest z prawidłowością ich funkcjonowania i umiejętnością wykorzystania rezultatów oceny. Niewłaściwie prowadzony i niedostosowany do specyfiki organizacji system oceniania okresowego szkodzi efektywności pracowników ${ }^{4}$. Specjaliści zajmujący się problematyką oceniania okresowego są zgodni, że jednym z podstawowych problemów oceniania okresowego jest brak lub niewłaściwe powiązanie go z innymi elementami polityki personalnej $j^{5}$ Ocena okresowa może $\mathrm{w}$ istotnym zakresie wspomagać zarządzanie, ale to, w jakim stopniu to wspomaganie będzie realizowane, zależy nie tylko od poprawności skonstruowania tego systemu, ale też od zakresu i siły powiązań oceniania z rozwiązaniami w poszczególnych obszarach zarządzania zasobami ludzkimi ${ }^{6}$. To powiązanie zależy m.in. od tego, na ile wyniki oceny okresowej są wykorzystywane w decyzjach kadrowych dotyczących tych obszarów. Skuteczność narzędzia, jakim jest ocena okresowa pracowników w zarządzaniu organizacją, zależy od jego spójności m.in. z rozwiązaniami w zakresie pozyskiwania pracowników, rozwoju potencjału już

\footnotetext{
${ }^{*}$ Doktorantka, Katedra Zarządzania Zasobami Ludzkimi, Wydział Zarządzania UŁ.

${ }^{1}$ F. O. Boachie-Mensah, Employees' perception of performance appraisal system: A case study, ,International Journal of Business and Management” 2012, vol. 7, no. 2, s. 73.

${ }^{2}$ D. Daley, Performance appraisal as a guide for training and development: A research note on the iowa performance evaluation system, ,Public Personel Management Journal” 1983, s. 159.

3 M.A. Mulvaney i in., The Development of a pay-for-performance appraisal system for municipal agencie: A case study, „Public Personel Management” 2012, s. 505.

${ }^{4}$ M. Sidor-Rządkowska, Ksztaltowanie nowoczesnych systemów ocen pracowników, Oficyna Ekonomiczna, Kraków 2000, s. 195.

${ }^{5}$ M. Sidor-Rządkowska, Kompetencyjne systemy ocen pracowników. Przygotowanie, wdrażanie i integrowanie z innymi systemami ZZL, Wolters Kluwer Polska, Warszawa 2011, s. 53.

${ }^{6}$ J. Dzieńdziora, Ocenianie pracowników. Ujęcie teoretyczne i praktyczne, Oficyna Wydawnicza „Humanitas”, Sosnowiec 2008, s. 35.
} 
zatrudnionych czy wynagradzania ${ }^{7}$. Można więc powiedzieć, że skuteczność oceniania zależy od odpowiedniego powiązania wyniku oceny $\mathrm{z}$ decyzjami wpływającymi na sytuację zawodową pracownika ${ }^{8}$. W przeciwnym razie jego istnienie staje się tylko źródłem dodatkowych kosztów (chociażby czas, który pracownicy i przełożeni poświęcają na udział $\mathrm{w}$ tym procesie) i negatywnych emocji związanych m.in. z brakiem wpływu oceny na pracę osób ocenianych'.

Tak, jak wcześniej wspomniano, powiązanie systemu oceniania z innymi elementami polityki personalnej jest bardzo potrzebne, a systemy, które tego nie realizują, nie tylko nie spełniają swojej funkcji, ale również są źle odbierane przez pracowników.

Należy również zwrócić uwagę, że znajomość systemu oceniania okresowego przez pracowników ma duży wpływ na ich opinię w tym zakresie, ale co istotniejsze wiąże się z jego efektywnością. Nawet najlepszy system, którego pracownicy nie rozumieją, nie jest $\mathrm{w}$ stanie spełnić swojej roli. Wiedza o systemie, jego elementach, procedurach, następstwach wiąże się z szeregiem konsekwencji. Po pierwsze, wpływa na poziom akceptacji - posiadanie informacji daje możliwość świadomego zadecydowania, w jakim stopniu system spełnia oczekiwania pracownika. Tylko rozumiejąc zjawisko może on je zaakceptować. Po drugie, brak wiedzy powoduje negatywne emocje - lęk, niepewność, niechęć. Po trzecie, znajomość powiązań oceniania okresowego z innymi działaniami personalnymi może być dodatkowym czynnikiem motywującym do lepszej pracy. Po czwarte, system oceniania okresowego będzie dobrze funkcjonował, jeżeli pracownicy będą przekonani o jego ważności i przydatności ${ }^{10}-$ tylko $\mathrm{w}$ takim wypadku zaangażują się w proces oceny.

Celem niniejszego artykułu jest zwrócenie uwagi na rolę powiązań systemów oceniania z wybranymi elementami zarządzania zasobami ludzkimi oraz wskazanie problemów, jakie mogą pojawiać się w tym zakresie.

\section{Ocena okresowa a inne dzialania ze sfery zarządzania zasobami ludzkimi}

Umiejętnie przeprowadzona ocena okresowa powinna być podstawą opracowania systemu wynagrodzeń, określania potrzeb i przesunięć kadrowych oraz rozwoju pracowników ${ }^{11}$.

${ }^{7}$ H. Czubasiewicz, Okresowe ocenianie pracowników. Konfiguracja i projektowanie syste$m u$, Wydawnictwo UG, Gdańsk 2005, s. 114.

${ }^{8}$ Ibidem.

${ }^{9}$ M.A. Mulvaney, W.R. McKinney, R. Grodsky, The Development..., s. 505.

${ }^{10}$ D. Kirkpatrick, Two ways to evaluate your performance appraisal system, ,Training and Development Journal" 1984, s. 39.

${ }^{11}$ Z. Janowska, Zarządzanie zasobami ludzkimi, PWE, Warszawa 2010, s. 245. 
M. Sidor-Rządkowska twierdzi, że ,warunkiem racjonalności systemu ocen okresowych jest ścisłe powiązanie go z wynagrodzeniami" "12. Rozwijając tę myśl, dodaje, że system oceniania jest przez pracowników odbierany jako sprawiedliwy tylko wtedy, gdy istnieje bezpośredni związek między wynikami oceny a wysokością otrzymanej premii czy nagrody. Systemy oceniania okresowego są efektywniejsze, jeżeli istnieje związek pomiędzy nimi a systemem wynagradzania $\mathrm{w}$ firmie ${ }^{13}$. Należy zwrócić również uwagę na aspekt motywacji finansowej takiego powiązania ${ }^{14}$. Właściwe powiązanie systemu oceniania i wynagrodzeń może być korzystne zarówno dla organizacji, jak i dla pracowników. H. Czubasiewicz dodatkowo zauważa, że ocena nie powinna być automatycznie przeliczana na wysokość wynagrodzenia, ale ma stanowić rzetelną podstawę do podjęcia $\mathrm{w}$ tej kwestii decyzji przez kierownika ${ }^{15}$. Powyższe wskazuje, jak istotne jest powiązanie systemu ocen z wynagrodzeniami, jednak należy zwrócić uwagę, że część organizacji takiego związku nie realizuje. Badania prowadzone $\mathrm{w}$ regionie łódzkim $\mathrm{w}$ latach 2003-2004 pokazały, że oceny pracownicze miały niewielki wpływ na politykę wynagradzania, ale i rozwoju ${ }^{16}$. Podobne problemy wykazano w przypadku części przedsiębiorstw uczestniczących w badaniu ogólnopolskim oraz w badaniu firm z województwa pomorskiego ${ }^{17}$.

Sprawny system oceniania okresowego jest również bardzo ważny dla polityki szkoleniowej firmy, ponieważ umożliwia on dokonanie rzetelnej analizy potrzeb szkoleniowych $\mathrm{w}$ organizacji ${ }^{18}$. Obisi twierdzi wręcz, że ich właściwe określenie jest możliwe tylko na podstawie wyników oceny pracowniczej ${ }^{19}$. System ocen powinien dawać możliwość określenia mocnych i słabych stron pracowników, to z kolei jest podstawą do ustalenia odpowiedniego dla każdego zatrudnionego planu szkoleń. Warto zwrócić uwagę, że w przypadku negatywnej oceny $\mathrm{w}$ dwóch $\mathrm{z}$ trzech przypadków rozwiązaniem jest skierowanie pracownika na odpowiednio dobrane szkolenia. $\mathrm{W}$ przypadku decyzji o pozostawieniu pracownika na dotychczasowym stanowisku, pod warunkiem uzupełnienia kwalifikacji (o ile przyczyna związana jest z brakiem wiedzy i umiejętności, a nie np. z niedopasowaniem osobowościowym), należy skierować go na potrzebne mu szkolenia. W przypadku konieczności przesunięcia pracownika na

${ }^{12}$ M. Sidor-Rządkowska, Ksztaltowanie nowoczesnych..., s. 173.

${ }^{13}$ E. Lawler, Rewards practices and performance management system effectiveness, „Organizational Dynamics" 2003, vol. 32, s. 396.

${ }^{14}$ H. Czubasiewicz, Okresowe ocenianie..., s. 115.

${ }^{15}$ Ibidem, s. 116.

${ }^{16}$ Z. Janowska, Zarządzanie zasobami..., s. 245.

${ }^{17}$ Ibidem.

${ }^{18}$ M. Sidor-Rządkowska, Kształtowanie nowoczesnych..., s. 175.

${ }^{19}$ C. Obisi, Employee performance appraisal and its implication for individual and organizational growth, „Australia Journal of Business and Management Research” 2011, vol. 1, s. 92. 
inne stanowisko dobór programu szkoleń wspierających to przesunięcie jest bardzo ważny dla powodzenia tego przedsięwzięcia. Ostatnia możliwość to decyzja o zwolnieniu pracownika - traktowane jest ono jako ostateczność i stosowane, gdy nie widać żadnych szans poprawy.

Dobrze dobrane szkolenia będą traktowane jako nagroda, będą wyrażać przekonanie przełożonego o możliwościach rozwojowych pracownika. Z kolei szkolenia nie odpowiadające potrzebom pracowników mogą powodować demotywację i niezadowolenie z polityki personalnej organizacji. Należy pamiętać, że szkolenia nie mogą być tylko nagrodą dla pracowników, którzy zostali dobrze ocenieni, ponieważ częstą przyczyną braku dobrych wyników w pracy jest właśnie brak umiejętności. W takich wypadku określenie zakresu potrzebnych szkoleń może stanowić silny bodziec motywujący do pracy i poprawy jej wyników ${ }^{20}$.

System oceniania pomaga przeanalizować spełnianie wymagań stanowiska przez pracownika, czyli określić, czy zatrudniony posiada wystarczającą wiedzę i umiejętności, aby efektywnie realizować swoje obowiązki. Niezależnie od przyczyny braku wiedzy czy umiejętności, poprawić sytuację może dobrze dobrane szkolenie. Porównanie wymagań stanowiska z wiedzą, umiejętnościami i predyspozycjami pracownika powinno być podstawą decyzji o awansie. Ocena okresowa pozwala określić aktualną wiedzę i umiejętności kandydata do awansu, jak również wskazać, które wymagania nowego stanowiska mogą okazać się problematyczne. Objęcie pracownika odpowiednio dobranym programem szkoleniowym może zapobiec sytuacji, w której osoba ta nie poradzi sobie na wyższym stanowisku.

M. Sidor-Rządkowska podkreśla, że polityka szkoleniowa będzie efektywna, jeżeli oprze się ją na rzetelnie przygotowanym i przeprowadzanym systemie okresowych ocen pracowniczych ${ }^{21}$. Warto zwrócić uwagę, że powiązanie oceny okresowej z polityką szkoleniową jest najczęstszym sposobem wykorzystywania wyników oceny ${ }^{22}$. Potwierdzają to badania firm $z$ województwa pomorskiego przeprowadzone przez H. Czubasiewicz. Pokazały one, że w większości badanych organizacji takie powiązanie występuje ${ }^{23}$.

Systemy oceniania okresowego są szczególnie ważne dla efektywnego wykorzystania kapitału ludzkiego nie tylko ze względu na ich znaczący wpływ na określanie potrzeb szkoleniowych, ale również na rozwój karier zawodowych pracowników $^{24}$. Ocenianie pracy jest bowiem konieczne dla kreowania rozwoju

${ }^{20}$ H. Czubasiewicz, Okresowe ocenianie..., s. 116.

${ }^{21}$ M. Sidor-Rządkowska, Kształtowanie nowoczesnych..., s. 178.

${ }^{22}$ H. Czubasiewicz, Okresowe ocenianie ..., s. 116.

${ }^{23}$ Z. Janowska, Zarządzanie zasobami..., s. 245.

${ }^{24}$ J. Clifton, Conversation analysis in dialogue with stocks of interactional knowledge: Facework and appraisal interview, „Journal of Business Communication” 2012, s. 283. 
zawodowego zatrudnionych ${ }^{25}$. Ważne jest, aby zdiagnozowane mocne i słabe strony wykorzystywać nie tylko do ustalenia noty pracownika (czy też jego miejsca w rankingu), ale również w celach rozwojowych i szkoleniowych. Jest to szczególnie istotne $\mathrm{w}$ przypadku pracowników, u których zauważono konieczność poprawy. Takie podejście pozwala pomóc przezwyciężyć pracownikowi jego trudności ${ }^{26}$. Ocenianie okresowe jest również związane z planowaniem ścieżki kariery zawodowej pracowników, w tym z awansami. Wynika to $\mathrm{z}$ możliwości diagnozy potencjału pracownika $\mathrm{w}$ trakcie oceny ${ }^{27}$. To podczas rozmów oceniających dyskutowane są kwestie związane $\mathrm{z}$ realizacją planów rozwoju zawodowego, trudności, jakie się pojawiły oraz wprowadzane są modyfikacje tych planów ${ }^{28}$. Przełożony, pełniąc funkcję „oceniającego”, jest źródłem informacji zwrotnych na temat wyników, pomaga rozwijać zachowania pozytywne i eliminować te negatywne ${ }^{29}$. To bezpośredni przełożony może w największym stopniu poznać aspiracje, ale i zdolności pracownika, m.in. podczas procesu oceniania okresowego. Poznanie możliwości i potrzeb pracowników jest podstawowym elementem budowania ich ścieżek kariery. M. Sidor-Rządkowska zwraca uwagę na problemy, jakie mogą wynikać z odchodzenia wykwalifikowanych pracowników i podkreśla, że kształtowanie ścieżek kariery oparte na dobrze funkcjonującym systemie oceniania okresowego jest jednym ze sposobów niedoprowadzania do takich sytuacji ${ }^{30}$.

System oceniania okresowego wykorzystywany jest również do zwalniania osób, które nie wywiązują się ze swoich obowiązków ${ }^{31}$. Negatywne oceny, prowadzące do zwolnienia, niestety nie zawsze są uzasadnione i w pełni obiektywne. Mogą wiązać się chociażby $\mathrm{z}$ konfliktem pomiędzy przełożonym a ocenianym pracownikiem. M. Sidor-Rządkowska zwraca uwagę, że nawet obiektywnie uzasadnione zwolnienie pracownika może być postrzegane przez jego kolegów jako niesprawiedliwe i negatywnie wpływać na pozostałych zatrudnionych $^{32}$. Dlatego bardzo ważnym etapem procesu derekrutacji jest wyjaśnienie przyczyn zwolnienia, nie tylko pracownikowi, którego to bezpośrednio dotyczy, ale również jego otoczeniu. Na ogół problemy z pracownikiem narastają przez dłuższy okres, czasem nawet kilka lat. Dlatego właściwie prowadzone ocenianie

${ }^{25}$ B. Urbanek, P. Bohdziewicz, Zarządzanie zasobami ludzkimi. Kreowanie nowoczesności. Raport 2005, IPISS, Warszawa 2005, s. 62.

${ }^{26}$ D. Daley, Performance Appraisal..., s. 165.

${ }^{27}$ H. Czubasiewicz, Okresowe ocenianie..., s. 117.

${ }^{28}$ M. Sidor-Rządkowska, Kształtowanie nowoczesnych..., s. 181.

${ }^{29}$ Ibidem, s. 187.

${ }^{30}$ Ibidem, s. 189.

${ }^{31}$ C. Grund, D. Sliwka, The anatomy of performance appraisals in Germany, ,The Internatonal Journal of Human Resource Management” 2009, vol. 20, no. 10, s. 2050.

${ }^{32}$ M. Sidor-Rządkowska, Kształtowanie nowoczesnych..., s. 189. 
okresowe może być szansą na uniknięcie tego ostatecznego rozwiązania. System oceniania daje bowiem możliwość rozwiązywania problemów, zanim będą one na tyle poważne, że jedynym wyjściem będzie zwolnienie ${ }^{33}$.

\section{Powiązania oceniania okresowego $\mathrm{z}$ innymi działaniami ze sfery realizacji funkcji personalnej w świetle badań własnych}

Przeprowadzone przez autorkę badania mają służyć refleksji nad potencjalnymi problemami spójnego współistnienia systemów oceniania okresowego $\mathrm{z}$ innymi obszarami zarządzania zasobami ludzkimi w przedsiębiorstwach działających na polskim rynku. Ze względu na małą liczebność próby (33 osoby) i dobór celowy (o opinię zostali poproszeni pracujący studenci, którzy podlegają ocenianiu okresowemu) badania te mogą być traktowane tylko jako materiał wstępnie ukierunkowujący uwagę na potencjalne źródła problemów efektywnego wykorzystania możliwości, jakie dają systemy oceniania okresowego. Respondentom zadano pytania badające ich opinię na temat wpływu ocen okresowych na inne elementy polityki personalnej oraz przekonanie pracowników o znaczeniu, jakie taka ocena ma dla jakości ich pracy. W przypadku pierwszej części (badanie związku ocen okresowych z innymi elementami polityki personalnej) zaproponowano badanym 5 odpowiedzi do wyboru: wiem, że tak, myślę, że tak, nie wiem, myślę, że nie, wiem, że nie. Rozróżnienie odpowiedzi pod względem pewności posiadanej wiedzy jest istotne ze względu na dokonywaną $\mathrm{w}$ ten sposób pośrednią ocenę znajomości systemu oceniania. Założono, że osoby, które wiedzą, jak funkcjonuje system oceniania w ich organizacji (ponieważ zostały o tym poinformowane, dostają informację zwrotną, czy też uczestniczyły w ocenianiu więcej razy), będą bardziej skłonne decydować się na odpowiedzi: „wiem, że tak” czy „wiem, że nie”, natomiast te, które swoją wiedzę o systemie opierają bardziej na obserwacji, nie są pewne związku innych elementów działań kadrowych z wynikiem oceniania, chętniej będą wybierały odpowiedzi „myślę, że tak”, „myślę, że nie”.

Pierwszym badanym przez autorkę obszarem były powiązania ocen okresowych z systemem wynagrodzeń. Respondentom zadano dwa pytania dotyczące tego obszaru polityki personalnej. Pierwsze dotyczy wpływu oceny okresowej na wynagrodzenie zasadnicze, drugie zaś wpływu oceny na przyznanie premii czy nagrody. W przypadku pierwszego pytania aż 18 osób (czyli ponad połowa badanej grupy) udzieliła odpowiedzi zaprzeczającej takiemu związkowi. $\mathrm{W}$ grupie tej tyle samo osób jest $\mathrm{w}$ pełni przekonanych, że taka relacja nie istnieje i tych, które się tego domyślają (z czego można wnioskować, że ich osobiście prawdopodobnie takie powiązanie nie dotyczy). 11 osób stwierdziło,

\footnotetext{
${ }^{33}$ Ibidem, s. 190.
} 
że taki związek istnieje (33\%). Tylko 4 osoby uznały, że nie mają wiedzy na ten temat. Odpowiedzi na drugie pytanie przedstawiają się odwrotnie - 20 osób (czyli ponad 60\%) uważa, że ocena okresowa wpływa na przyznanie nagrody czy premii, z czego 15 (ponad 45\%) jest tego pewnych. 9 osób (27\%) takiego związku nie widzi. Podobnie jak w pierwszym pytaniu 4 osoby nie wiedzą, czy taka relacja przyczynowo-skutkowa występuje. Łączna analiza tych dwóch pytań pokazała, że wszystkie osoby, które stwierdziły, że wiedzą, że ocena okresowa ma wpływ na wynagrodzenie zasadnicze, są też pewne, że ma ona wpływ na przyznane nagrody czy premie.

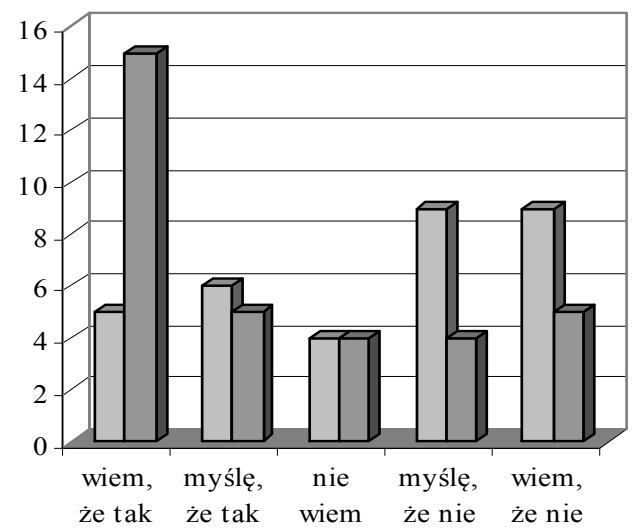

Czy ocena okresowa wpły wa na wynagrodzenie zasadnicze?

Czy ocena okresowa wpływa na przyznanie premii / nagrody?

Rysunek 1. Opinie badanych na temat wpływu oceny okresowej na wynagrodzenie zasadnicze oraz przyznanie premii/nagrody

Źródło: opracowanie własne.

W przypadku osób, które wybrały odpowiedź pozytywną o mniejszym stopniu pewności (myślę, że tak) na pierwsze pytanie, wszystkie widzą również związek ocen z nagrodami czy premiami. Można więc powiedzieć, że w organizacjach, w których powiązano wysokość wynagrodzenia zasadniczego z wynikami oceny okresowej, dokonano również przełożenia wyników ocen na premie i nagrody. Nie można natomiast powiedzieć, że powiązanie oceniania z premiowaniem automatycznie oznacza również połączenie go z kształtowaniem wynagrodzeń zasadniczych. 8 osób, które uważają, że ocena wpływa na premie, uważa jednocześnie, że związku oceniania z wynagrodzeniem zasadniczym nie ma.

Wśród osób, które uważają, że wynagrodzenie zasadnicze nie zależy od wyników oceny, nie ma już tak dużej zgodności odpowiedzi na pytanie dotyczące związków oceny z premiami i nagrodami. Mimo to można zauważyć, że połowa osób, które odpowiedziały negatywnie (myślę, że nie i wiem, że nie), uważa, że nie ma również związku między ocenami a przyznaniem premii czy nagrody. Prawie drugie tyle uważa jednak, że taki związek występuje. Może to wskazywać na to, że premie i nagrody częściej są wiązane z wynikami oceny 
niż wynagrodzenia zasadnicze. Takie powiązanie wydaje się łatwiejsze, m.in. ze względu na jego jednorazowość, która wiąże się z mniej poważnymi konsekwencjami zarówno dla organizacji, jak i dla ocenianych pracowników.

Nawiązując do rozważań na temat roli oceniania okresowego w procesie analizy potrzeb szkoleniowych, zapytano osoby badane, czy ocena okresowa wpływa na udział w szkoleniach. Odpowiedzi pokazują, że prawie $40 \%$ (13 osób) wie lub myśli, że udział w szkoleniach jest powiązany z oceną okresową, a ponad $42 \%$ (14 osób) uważa przeciwnie. 6 osób nie posiada wiedzy w tym zakresie. Przekonanie tak stosunkowo dużej części osób o braku związku pomiędzy oceną okresową a polityką szkoleniową organizacji jest niepokojące. Warto zauważyć, że odnoszenie wyników oceny okresowej do planowania potrzeb szkoleniowych jest tym powiązaniem oceniania $z$ innymi elementami polityki personalnej, które ma miejsce najczęściej i najchętniej jest stosowane ${ }^{34}$. W badaniu nie analizowano poprawności wykorzystania wyników oceny do analizy potrzeb szkoleniowych.

Aby określić stopień wykorzystania ocen okresowych w celu rozwoju zawodowego pracowników, respondenci zostali poproszeni o określenie, czy ocena okresowa pomaga im dostrzec ich silne strony i słabości, uzyskiwać lepsze wyniki $\mathrm{w}$ pracy oraz czy ocena zawodowa wpływa na przesunięcia na inne stanowiska oraz awanse. Zadano również ogólne pytanie o związek oceny okresowej z rozwojem zawodowym.

Przeważająca część badanych stwierdziła, że ocena okresowa pomaga im zarówno dostrzec silne strony, jak i słabości (odpowiednio 27 i 26 osób udzieliło odpowiedzi ,tak” i ,raczej tak”).

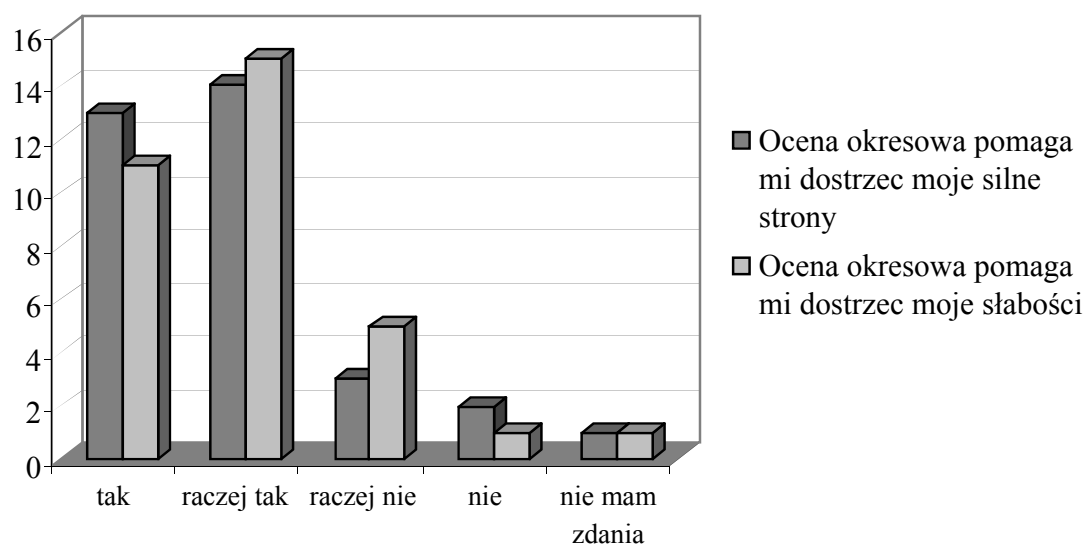

Rysunek 2. Subiektywna ocena wpływu oceny okresowej na określenie silnych i słabych stron Źródło: opracowanie własne.

${ }^{34}$ H. Czubasiewicz, Okresowe ocenianie..., s. 116. 
Rozwój zawodowy pracownika to również osiąganie przez niego coraz lepszych rezultatów w pracy. W związku z tym zapytano respondentów, czy ocena okresowa pomaga im osiągać lepsze rezultaty w pracy i określić, co powinni poprawić w swoim zachowaniu czy sposobie pracy. Uzyskane odpowiedzi są stosunkowo optymistyczne. 20 osób stwierdziło, że ocena okresowa jest pomocna w osiąganiu lepszych wyników pracy, 27 - że ocena wskazuje, co powinno zostać poprawione w zachowaniu lub sposobie pracy zatrudnionego. Odpowiednio przeciwnego zdania jest 11 i 5 osób.

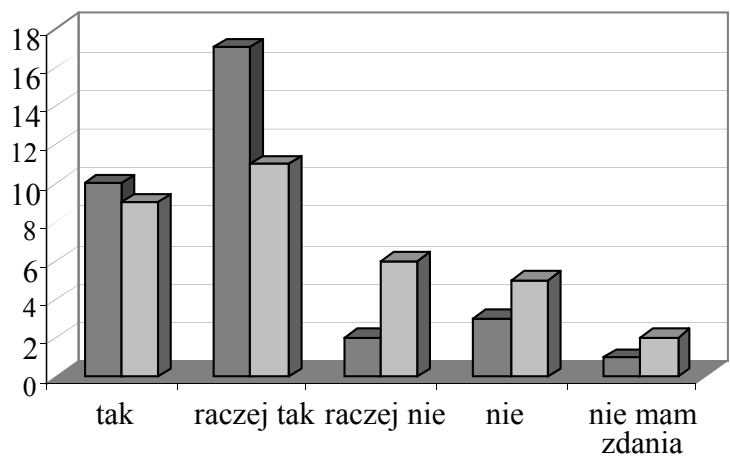

$\square$ Ocena okresowa pomaga mi określić, co powinnam/powinienem poprawić w moim zachowaniu

$\square$ Ocena okresowa pomaga mi osiagać lepsze rezultaty w pracy

Rysunek 3. Ocena okresowa a osiąganie lepszych rezultatów w pracy Źródło: opracowanie własne.

Dokonano również analizy odpowiedzi na pytania o wpływ oceny okresowej na przesunięcia na inne stanowiska i awanse. Większość badanych jest przekonana, że ocena okresowa wiąże się zarówno z szeroko pojętymi przesunięciami na inne stanowiska, jak i awansami.

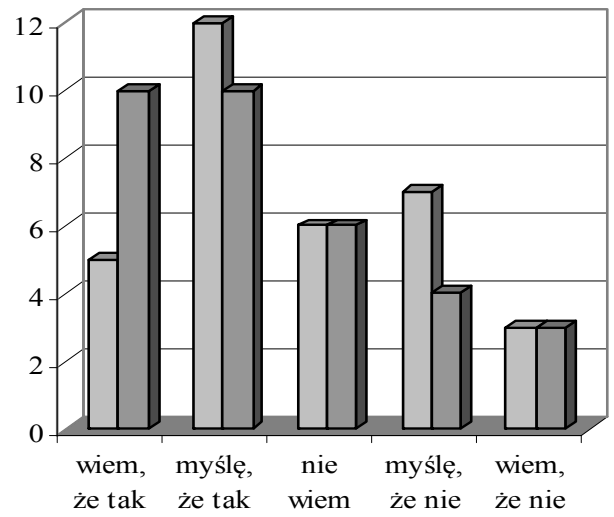

$\square$ Czy ocena okresowa ma wpływ na przesunięcia na inne stanowiska pracy?

$\square$ Czy ocena okresowa ma wpływ na awanse?

Rysunek 4. Subiektywna ocena wpływu oceny okresowej na przesunięcia na inne stanowiska

Źródło: opracowanie własne. pracy $i$ awanse 
Mimo tak stosunkowo dużej liczby osób przekonanych o wpływie oceny na dostrzeganie przez nich swoich mocnych i słabych stron i jej roli w osiąganiu lepszych wyników zaledwie połowa uważa, że ocena pomaga im rozwijać się zawodowo. Może to, po pierwsze, wskazywać na dość wąskie rozumienie przez ankietowanych pojęcia „rozwój zawodowy”, być może w kategoriach zdobywania nowej wiedzy podczas różnego typu szkoleń. Możliwe jest również wyjaśnienie, że badani dostrzegają związki oceny z awansowaniem, a awansowania z rozwojem zawodowym, ale nie wszyscy osobiście tego doświadczyli. Wydaje się, że poprawianie swoich wyników w pracy przez część badanych nie jest odbierane w kategoriach rozwoju zawodowego.

Ostatnim elementem polityki personalnej, którego związki z ocenianiem okresowym opiniowali respondenci jest derekrutacja. W omawianym badaniu, przekonanie o powiązaniu oceniania okresowego z derekrutacją jest stosunkowo wysokie - aż 18 respondentów stwierdziło, że ocena okresowa ma wpływ na zwolnienia. 9 sądzi, że takiego związku nie ma, a 1 osoba nie wie, czy zwolnienia są powiązane $\mathrm{z}$ ocenianiem.

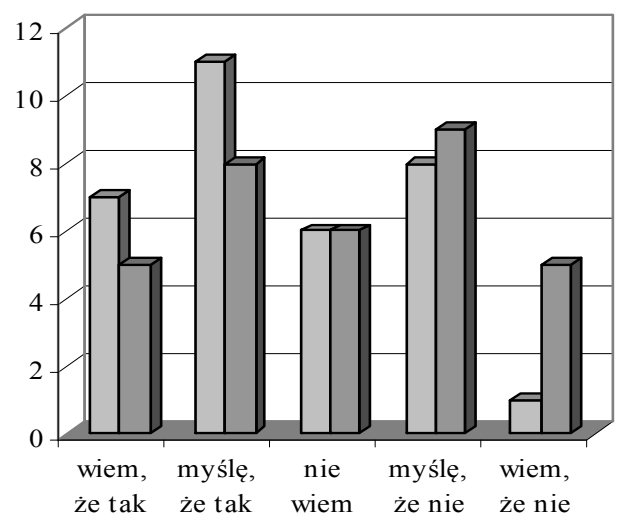

$\square$ Czy ocena okresowa ma wpływ na zwolnienia?

Czy ocena okresowa wpływa na udział w szkoleniach?

Rysunek 5. Subiektywna ocena wpływu oceny okresowej na zwolnienia i udział w szkoleniach Źródło: opracowanie własne.

Zwalnianie pracowników jest uważane za wyjście ostateczne, które należy stosować wtedy, kiedy pracownik nie daje nadziei na poprawę. Pojawia się pytanie, dlaczego badani w tak dużej części są przekonani o występowaniu związku między ocenianiem okresowym a zwalnianiem. Wydaje się, że możliwych jest kilka wyjaśnień. Po pierwsze, taka konsekwencja negatywnej oceny jest szczególnie trudna dla pracownika, więc zwraca on na nią bardziej uwagę, np. podczas szkolenia dotyczącego oceniania, czy zapoznawania się z regulaminem. Po drugie, być może badani bywają świadkami takiego biegu wydarzeń. Pracownicy oczywiście powinni mieć jak najszerszą wiedzę na temat systemu oceniania, jak również jego powiązań z innymi działaniami firmy. Niepokojące 
jest jednak większe przekonanie o związku oceny z derekrutacją niż ze szkoleniami czy rozwojem, który powinien być jednym z głównych motywów oceniania okresowego.

\section{Zakończenie}

System ocen okresowych powinien być realizowany zgodnie z zasadą celowości, czyli być powiązany z celami strategicznymi organizacji, wspierać jej misję oraz zasadą użyteczności, a więc powinien umożliwiać podejmowanie racjonalnych decyzji w zakresie polityki szkoleniowej, wynagrodzeń, kształtowania ścieżek kariery, awansowania czy przesunięć ${ }^{35}$. Sprzężenie zwrotne pomiędzy systemem oceniania okresowego a pozostałymi obszarami polityki kadrowej pozwala na zwiększenie racjonalności działań w jej zakresie ${ }^{36}$ Badania autorki pokazały, że organizacje próbują wykorzystywać ocenianie okresowe dla efektywniejszego kształtowania polityki kadrowej. Duża część badanych osób zauważa powiązania oceniania okresowego z innymi działaniami z zakresu zarządzania zasobami ludzkimi w ich organizacjach. Dość dobrze przedstawia się sytuacja w obrębie powiązań z polityką premiowania i awansowania. Cieszy również przekonanie badanych o roli, jaką ocenianie pełni w rozpoznawaniu przez nich swoich mocnych i słabych stron czy pozytywnej roli w poprawianiu wyników pracy. Niepokojący z kolei jest poziom przekonania o wpływie oceniania np. na udział w szkoleniach. Pytaniem otwartym pozostaje, z czego taka opinia wynika. Czy wypowiadały się osoby, które osiągają dobre i bardzo dobre oceny i nie są kierowane na szkolenia, ponieważ potrzebują ich mniej niż inni, czy też rzeczywiście polityka szkoleniowa jest oderwana od wyników oceny, a potrzeby szkoleniowe są określane w inny sposób. Martwi również, że nawet w tak niewielkiej grupie znalazło się kilka osób, które nie wiedzą, czy takie związki w ogóle występują. Należy zwrócić uwagę, aby nie tylko zadbać o wpływ oceny okresowej na inne elementy zarządzania zasobami ludzkimi, ale również, aby ustalić jasne dla pracowników zasady tych powiązań. Prawidłowa komunikacja systemu jest kluczowa dla jego rozumienia przez pracowników, jego akceptacji i chęci udziału w procesie oceniania. To zaś z kolei wpływa na efektywność funkcjonowania takiego systemu. Należy zwrócić uwagę na konieczność aktualizacji systemu wraz z rozwojem organizacji i pracowników oraz dostosowanie go do potrzeb, w tym do zmian zachodzących w organizacji i w jej otoczeniu. W omawianym badaniu skupiono się na postrzeganiu różnych aspektów oceniania przez osoby oceniane. Subiektywne postrzeganie systemu ocenia-

${ }^{35}$ M. Sidor-Rządkowska, Kompetencyjne systemy..., s. 53.

${ }^{36}$ K. Atamańczuk, Ocena pracowników w strategii zarządzania zasobami ludzkimi, Wydawnictwo Uniwersytetu Warmińsko-Mazurskiego, Olsztyn 2001, s. 25. 
nia przez pracowników może różnić się od tego, jak ten system formalnie wygląda i funkcjonuje, ale na motywację pracowników do wydajniejszej pracy, do pozostania w firmie, do poprawiania swojej efektywności wpływ może mieć właśnie ich subiektywna opinia na temat systemu oceniania.

\section{Literatura}

Atamańczuk K., Ocena pracowników w strategii zarządzania zasobami ludzkimi, Wydawnictwo Uniwersytetu Warmińsko-Mazurskiego, Olsztyn 2001.

Boachie-Mensah F. O., Employees' perception of performance appraisal system: A case study, „International Journal of Business and Management” 2012, vol. 7, no. 2,

Clifton J., Conversation analysis in dialogue with stocks of interactional knowledge: Facework and appraisal interview, ,Journal of Business Communication” 2012, vol. 49, no. 4.

Czubasiewicz H., Okresowe ocenianie pracowników. Konfiguracja i projektowanie systemu, Wydawnictwo UG, Gdańsk 2005.

Daley D., Performance appraisal as a guide for training and development: A research note on the iowa performance evaluation system, „Public Personel Management Journal” 1983, vol. 12, no. 2.

Dzieńdziora, J., Ocenianie pracowników. Ujęcie teoretyczne I praktyczne, Oficyna Wydawnicza „Humanitas”, Sosnowiec 2008.

Grund C., Sliwka D., The anatomy of performance appraisals in Germany, „The Internatonal Journal of Human Resource Management" 2009, vol. 20, no. 10.

Janowska Z., Zarządzanie zasobami ludzkimi, PWE, Warszawa 2010.

Kirkpatrick D., Two ways to evaluate your performance appraisal system, „Training and Development Journal" 1984, vol. 38, no. 8.

Lawler E., Rewards practices and performance management system effectiveness, „Organizational Dynamics" 2003, vol. 32, no. 4.

Mulvaney M.A., McKinney W.R., Grodsky R., The Development of a Pay-for-Performance Appraisal System for Municipal Agencie: A case study, „Public Personel Management” 2012, vol. 41 , no. 3.

Obisi C., Employee performance appraisal and its implication for individual and organizational growth, „Australia Journal of Business and Management Research” 2011, vol. 1, no. 9.

Sidor-Rządkowska M., Kompetencyjne systemy ocen pracowników. Przygotowanie, wdrażanie i integrowanie z innymi systemami ZZL, Wolters Kluwer Polska Sp. z o.o., Warszawa 2011.

Sidor-Rządkowska M., Kształtowanie nowoczesnych systemów ocen pracowników, Oficyna Ekonomiczna, Kraków 2000.

Urbaniak B., Bohdziewicz P., Zarządzanie zasobami ludzkimi. Kreowanie nowoczesności. Raport 2005, IPISS, Warszawa 2005.

\section{Streszczenie}

Ocenianie okresowe pracowników jest procesem złożonym, a jednocześnie mającym zasadniczy wpływ na efektywne funkcjonowanie organizacji. Wpływ ten widoczny jest $\mathrm{w}$ powiązaniach systemu oceniania $\mathrm{z}$ innymi działaniami $\mathrm{z}$ zakresu realizacji funkcji personalnej. W artykule przedstawiono wybrane problemy współistnienia systemu oceniania z innymi elementami zarządzania zasobami ludzkimi, takimi jak kształ- 
towanie wynagrodzeń, polityka szkoleniowa, rozwój pracowników, czy derekrutacja. Przeprowadzone wstępne badania pokazały, że większość respondentów zauważa powiązania systemu oceniania $z$ innymi elementami polityki personalnej. Niepokojące jest jednak niedostrzeganie przez część osób badanych związku pomiędzy ocenianiem a udziałem w szkoleniach.

\section{Summary}

\section{PERFORMANCE APPRAISAL IN RELATION TO OTHER TOOLS IN HUMAN RESOURCES MANAGEMENT}

Performance appraisal is a complex process having a great importance for an effective functioning of every organization. It is a powerful tool, especially when combined with and reinforced by other measures available to human resources management. This article focuses precisely on performance appraisal in relation to such important factors as remuneration, training opportunities, personal development or possible dismissal of an employee. Initial research shows that the majority of respondents notice that appraisal results and other elements of human resources management are linked together. However many people do not see any relationship between periodic evaluation and availability of professional trainings. 